\title{
Analysis of upper-tropospheric humidity in tropical descent regions using observed and modelled radiances
}

V. O. John ${ }^{1}$, D. E. Parker ${ }^{1}$, S. A. Buehler ${ }^{2}$, J. Price ${ }^{1}$, and R. W. Saunders ${ }^{1}$

${ }^{1}$ Met Office Hadley Centre, Exeter, UK

${ }^{2}$ Department of Space Science, Lulea University of Technology, Kiruna, Sweden

Received: 7 March 2013 - Accepted: 9 April 2013 - Published: 22 April 2013

Correspondence to: V. O. John (viju.john@metoffice.gov.uk)

Published by Copernicus Publications on behalf of the European Geosciences Union.

UTH in tropical
descent regions

V. O. John et al.

\section{Title Page}

Abstract Introduction

Conclusions References

Tables Figures

14 DI

4

Back Close

Full Screen / Esc

Printer-friendly Version

Interactive Discussion 


\section{Abstract}

We use multiple observations and climate model simulations to study upper tropospheric humidity (UTH) in tropical descent regions. A satellite simulator is used to generate UTH from model fields to ensure a like-to-like comparison. We have shown that

5 HadGEM2 is generally able to reproduce the patterns and magnitude of UTH in these regions. In both models and observations, the major mode of UTH variability in these regions is associated with EI Nino and Southern Oscillation (ENSO); a negative UTH anomaly is seen during El Nino years. There is no significant trend in UTH in these regions, where even a small negative trend would lead to an important reduction of the positive water vapour feedback on global warming.

\section{Introduction}

Water vapour is one of the most important parameters controlling the weather and climate of our planet. However, we still lack a precise knowledge of the amount of water vapour in many parts of the atmosphere and a thorough understanding of the mechanisms which control its distribution. Many of the key radiative and meteorological interactions of water vapour are controlled by relative rather than specific humidity (e.g. Sherwood et al., 2010). Mid to upper tropospheric humidity is also linked to large scale dynamics of the atmosphere.

The tropical descent or subsidence regions play a dominant part in cooling our planet by emitting radiation back to space because of the dryness of the atmosphere and the absence of mid or high level clouds (Fasullo and Trenberth, 2012). In these regions, changes in relative humidity have a major impact on the outgoing longwave radiation (e.g. Roca et al., 2012). The concentration of water vapour in these regions is controlled by large scale subsidence drying, lateral mixing which brings moist air from convective regions, and net drying through condensation as the air passes through the colder extratropics (Pierrehumbert, 1998).
UTH in tropical descent regions

V. O. John et al.

Title Page

Abstract

Introduction

Conclusions

References

Tables

Figures

14

$\Delta \mathbf{I}$

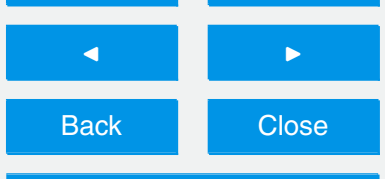

Full Screen / Esc

Printer-friendly Version

Interactive Discussion 
A strong positive feedback on global warming will result from water vapour unless relative humidity decreases rapidly as the climate warms (e.g. Allan, 2012). Increased amounts of water vapour in the atmosphere in a warmer climate have many effects on the hydrological cycle, for example extreme rainfall (Allan and Soden, 2008).

5 Current climate models have substantial biases in the representation of water vapour in the troposphere (e.g. Pierce et al., 2006; John and Soden, 2007). Compared to Atmospheric Infrared Sounder (AIRS) and reanalysis humidity profiles, on average, current climate models simulate a large moist bias in the free troposphere and the bias varies significantly from one model to the next. In contrast, the response of water 10 vapour to a surface warming is shown to be remarkably consistent across models and uncorrelated to the bias in the mean state. The inter-tropical belt, including the tropics and the subtropics, is the region responsible for most of the water vapour feedback and where humidity departs most from saturation (Held and Soden, 2000). Models show largest biases in these regions (e.g. Pierce et al., 2006). However, John and 15 Soden (2007) showed that these biases, while significant, have little direct impact on the model's simulation of a robust positive water vapour feedback.

Lindzen et al. (2001) postulated that cloud micro/macro physical effects can cause UTH to decrease significantly with warming. However, several studies disputed this idea (e.g. Hartmann and Michelsen, 2002). Sherwood et al. (2010) pointed out that Lindzen et al. (2001) tested their hypothesis in an atmosphere-only GCM, but in reality, the sea surface temperature (SST) in their study area $\left(30^{\circ} \mathrm{S}-30^{\circ} \mathrm{N} ; 130-170^{\circ} \mathrm{E}\right)$ is coupled with ocean heat fluxes and warms under cloud free conditions. Sherwood et al. (2010) also showed using coupled climate models that the correlations shown by Lindzen et al. (2001) cannot give any insight into the water vapour feedback on climate.

$25 \quad$ Held and Soden (2006) suggested that a muted increase in precipitation (only about $2 \%$ compared to the $7 \%$ increase in water vapour) will result in a slowing down of overturning circulations in the atmosphere. However, Shi and Bates (2011) analysed homogenised upper tropospheric water vapour radiances from the High-resolution Infrared Sounder (HIRS) instrument. They examined trends in the number of grid points
ACPD

13, 10547-10560, 2013

UTH in tropical

descent regions

V. O. John et al.

Title Page

Abstract

Introduction

Conclusions

References

Tables

Figures

14

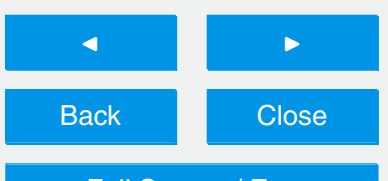

Full Screen / Esc

Printer-friendly Version

Interactive Discussion 
of high UTH (more than $30 \% \mathrm{RH}$ ) and low UTH (less than $20 \% \mathrm{RH}$ ) and found that there are increasing trends in both cases, indicating enhanced convective activity in the tropics. Sohn and Park (2010) have shown, using observed and reanalysed data, that the strength of both Hadley and Walker circulations has intensified since 1979. To 5 corroborate this they used upper tropospheric humidity and total column water vapor and showed that the subsidence region has become drier because of the increased sinking motion.

The objectives of this letter are to assess the patterns, magnitude and variability of UTH in a current climate model used in the IPCC AR5 simulations and to check 10 whether observations or model produce any significant trends in UTH which would have a profound impact on water vapour feedback and thus on the magnitude of global warming. We found that the model is able to reproduce observed UTH and neither model nor observations show any significant trend in upper UTH in tropical descent regions.

\section{Data and method}

\subsection{Satellite data}

We use satellite data from two different instruments: one is HIRS which measures upper tropospheric humidity using an infrared (IR) channel (at $6.7 \mu \mathrm{m}$ ) and the other is the Advanced Microwave Sounding Unit (AMSU) which uses a microwave (MW) channel (at $183.31 \pm 1.00 \mathrm{GHz}$ ). We will refer to these channels as microwave or infrared UTH channel. The HIRS data are restricted to clear-sky pixels and homogenised (Shi and Bates, 2011): monthly gridded data were obtained from NOAA/NCDC. HIRS data are used only for the time series analysis. We use them because of their long term availability. In this study we used HIRS data for 1989-2008. The AMSU-B data were quality controlled and bias corrected based on John et al. (2013a,b). AMSU-B data are used for $10 \mathrm{yr}$ from 1999 to 2008.
ACPD

13, 10547-10560, 2013

UTH in tropical

descent regions

V. O. John et al.

Title Page

Abstract

Introduction

Conclusions

References

Tables

Figures

14

$>1$

4

Back

$>$

Close

Full Screen / Esc

Printer-friendly Version

Interactive Discussion 
Microwave top of atmosphere radiance measurements are affected only by precipitating/deep convective clouds, and measurements contaminated by such clouds are filtered out using a method described in Buehler et al. (2007). As cloudiness is correlated with humidity, filtering out the cloudy/high humidity values could introduce a small $5(2-3 \% \mathrm{RH})$ dry bias in the observed UTH in convectively active areas (Buehler et al., 2008). However, for HIRS data cloud contamination is a severe problem. John et al. (2011) have clearly demonstrated using microwave UTH data that clear-sky HIRS UTH data suffer from a dry bias of up to $30 \% \mathrm{RH}$ or more in convective regions. They have also shown that the clear-sky only sampling of HIRS can lead to biased estimates of o inter-annual variability and trend. Fortunately we largely avoid this problem because we focus on the descent regions where both IR and MW data are good and similarly sampled. Note that we use HIRS data only in the time series analysis.

\subsection{Estimation of UTH from measurements}

The upper tropospheric humidity can be related to measurements by satellite radiometer channels which are sensitive to the water vapour concentration in layers between approximately 500 and $200 \mathrm{hPa}$. As demonstrated by Soden and Bretherton (1996) and Buehler and John (2005), the natural logarithm of a variable hereafter referred to as UTH is linearly related to the radiance measured by a UTH channel:

$\ln (\mathrm{UTH})=a+b \cdot T_{\mathrm{B}}$

20 where $a$ and $b$ are regression coefficients which were pre-defined using a diverse atmospheric profile data set. $T_{\mathrm{B}}$ is the UTH channel radiance expressed as an equivalent black body brightness temperature. HIRS radiances were already limb corrected. Microwave UTH data need not be limb corrected as appropriate conversion coefficients were used for each angle (John et al., 2006) and the data have been validated using high quality radiosondes and satellite measurements (e.g. Milz et al., 2009; Moradi et al., 2010; Kottayil et al., 2012).
ACPD

13, 10547-10560, 2013

UTH in tropical descent regions

V. O. John et al.

Title Page

Abstract Introduction

Conclusions References

Tables Figures

14

4

Back

Full Screen / Esc

Printer-friendly Version

Interactive Discussion 


\subsection{UTH simulations from climate model}

Our model data are from the atmospheric component of HadGEM2 (Collins et al., 2008) forced with observed SST and sea ice using HadISST (Rayner et al., 2003) and with natural and anthropogenic forcings. The use of observed sea surface temperature en5 sures that El Nino-Southern Oscillation (ENSO) activity, which has major effects on tropical tropospheric moisture, coincide in observations and model. To estimate UTH from HadGEM2, we use the RTTOV radiative transfer model under the framework of the CFMIP Observation Simulator Package (COSP; Bodas-Salcedo et al., 2011) to compute the radiances which would be measured by the UTH channels for the model atmosphere. These radiances are then converted to UTH using the same $a$ and $b$ parameters which were used to estimate observed UTH, to ensure a like-to-like comparison.

\subsection{Methodology}

Generally, analysis of ascent/descent regions is done using fixed areas (e.g. Sohn and 15 Park, 2010; Eliasson et al., 2011), but the accuracy of this approach is compromised by the seasonally varying inter-tropical convergence zone (ITCZ). Another way of separating ascent/descent regions is by using $500 \mathrm{hPa}$ vertical velocity (e.g. Brogniez and Pierrehumbert, 2007; John et al., 2009). We used the $500 \mathrm{hPa}$ vertical velocity from the ERA-Interim reanalysis to allocate observed UTH to descent regions. Modelled UTH are classified using the model's own vertical velocity. This has the advantage that any differences between model and observations originating from mismatches of dynamical regimes are minimised (e.g. Brogniez and Pierrehumbert, 2007).

\section{Results and discussion}

Figure 1 shows modelled and observed descent region $10 \mathrm{yr}$ (1999-2008) UTH cli25 matology for January (left panels) and July (right panels). The shift of the ITCZ from 10552

\section{ACPD}

13, 10547-10560, 2013

UTH in tropical

descent regions

V. O. John et al.

Title Page

Abstract

Introduction

Conclusions

References

Tables

Figures

14

$\Delta \mathbf{I}$

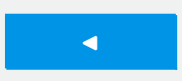

Back

$\triangleright$

Close

Full Screen / Esc

Printer-friendly Version

Interactive Discussion 
Southern Hemisphere in January to Northern Hemisphere in July is evident in the UTH climatology fields which reflect the large scale circulation dependence of the UTH distribution. Core subsidence regions show UTH climatology values of $20 \% \mathrm{RH}$ or less. In general, HadGEM2 is very good in reproducing the observed patterns and magni5 tude of UTH in those regions, but there are some spatial mismatches and biases. For example, in the southern Indian Ocean during July, the model is wetter than observations. This may indicate a weak return flow of the monsoon circulation in the model. HadGEM2 is known to have problems in simulating the monsoon rainfall (Collins et al., 2008).

10 Figure 2 shows the frequency distributions of UTH in descent regions in AMSU-B data and in HadGEM-2. The distribution of UTH is not Gaussian, but it is closer to a log-normal distribution (e.g. John et al., 2006; Sherwood et al., 2010). HadGEM2 has a higher number of high UTH values which indicates that the model is unable to simulate some of the key circulation features such as monsoons as explained above. The median of UTH in HadGEM2 simulation is $24.01 \% \mathrm{RH}$ and in AMSU-B it is $22.25 \% \mathrm{RH}$.

Figure 3 shows time-series of area-weighted average of UTH in tropical descent regions for HadGEM2, AMSU-B, and also for HIRS. The inter-annual variability of simulated and observed time series are very similar. Pronounced UTH negative anomalies can be observed during the 91/92 (mainly in the model), 97/98, and 02/03 El Nino events. McCarthy and Toumi (2004), using HIRS UTH data, have identified ENSO as the principal mode of inter-annual variability in global UTH, but no significant impact on UTH averaged over the entire tropical zone $\left(30^{\circ} \mathrm{S}-30^{\circ} \mathrm{N}\right)$. However, we found that EI Nino tends to reduce UTH in tropical descent regions. The AMSU-B and HIRS UTH time series agree well $(r=0.83)$ over their common time period (1999-2008).

A small trend to lower UTH in the dry subsidence regions would have an important impact on OLR; weakening the water vapour positive feedback (e.g. Roca et al., 2012). But neither the observations $(0.00 \% \mathrm{RH}$ per decade for HIRS and $-0.01 \% \mathrm{RH}$ per decade for AMSU-B) nor the model ( $0.00 \% \mathrm{RH}$ per decade) show any statistically significant trend for UTH in the descending region for the analysed time period. Sohn
ACPD

13, 10547-10560, 2013

UTH in tropical

descent regions

V. O. John et al.

Title Page

Abstract

Introduction

Conclusions

References

Tables

Figures

14

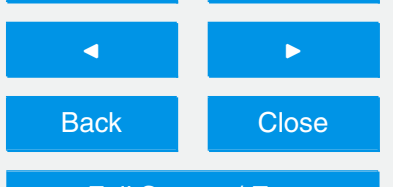

Full Screen / Esc

Printer-friendly Version

Interactive Discussion 
and Park (2010) have reported a decreasing UTH trend over a fixed descending region $\left(150-195^{\circ} \mathrm{E}, 7.5-15^{\circ} \mathrm{N}\right)$ in a particular season (December-February), but the chosen region was not explicitly defined by $500 \mathrm{hPa}$ vertical velocity and may not have been representative of tropical descent regions as a whole. Our definition using $500 \mathrm{hPa}$ 5 vertical velocity is superior so long as the reanalysis vertical velocity fields are reliable.

It is clear from the analysis that the model can reproduce the observed distribution and variability of UTH in tropical descent regions. The model is also consistent in producing no significant trend in UTH.

\section{Conclusions}

10 We have shown using infrared and microwave observations of UTH that the major mode of inter-annual variability of UTH in tropical descent regions is associated with EI Nino. The observations do not show a significant trend in UTH during 1988-2009 over those regions. We also used the satellite simulator COSP to generate the radiances which the UTH channel would have seen from the HadGEM2 model atmosphere, given observed SSTs. This ensures a like-to-like comparison of observed and modelled UTH. We used reanalysis $500 \mathrm{hPa}$ vertical velocity fields to define the descending areas in observations and the model's own vertical velocity to define its descending areas so that errors owing to spatial mismatches are minimised in our analysis. This is important for UTH analysis because UTH values are very much dependent on the dynamic

20 regime. The HadGEM2 SST forced run successfully reproduces the observed patterns and magnitude of UTH, as well as negative anomalies of UTH during El Nino years as observed. And, like the observations, the model does not show any significant trend in UTH over the analysed time period. Our analysis, however, pointed to a problem of HadGEM2 in simulating monsoon circulation.

25 Acknowledgements. VOJ and DEP were supported by the DECC/Defra Met Office Hadley Centre Climate Programme (GA01101). VOJ was also supported by the UK JWCRP and the EUMETSAT CMSAF. JP was funded by EUMETSAT CMSAF. This work contributes to COST 10554

\section{ACPD}

13, 10547-10560, 2013

UTH in tropical descent regions

V. O. John et al.

Title Page

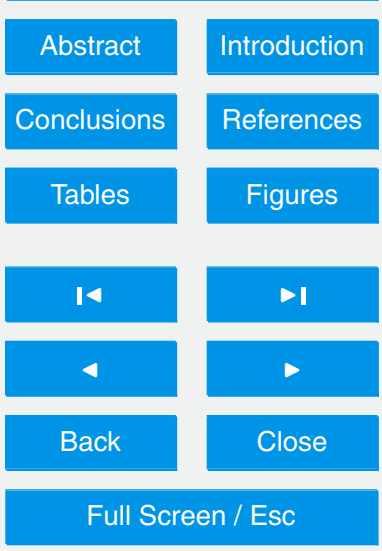

Printer-friendly Version

Interactive Discussion 
Action ES604 - Water Vapor in the Climate System (WaVaCS). Thanks to Lisa Neclos of the NOAA CLASS for AMSU-B and MHS Level-1b data, EUMETSAT NWP-SAF for the AAPP software to process the data and RTTOV and NOAA/NCDC for HIRS data.

\section{References}

5 Allan, R. P.: The role of water vapour in Earth's energy flows, Surv. Geophys., 33, 557-564, doi:10.1007/s10712-011-9157-8, 2012. 10549

Allan, R. P. and Soden, B. J.: Atmospheric warming and the amplification of precipitation extremes, Science, 321, 1481-1484, doi:10.1126/science.1160787, 2008. 10549

Bodas-Salcedo, A., Webb, M. J., Bony, S., Chepfer, H., Dufresne, J.-L., Klein, S. A., 10 Zhang, Y., Marchand, R., Haynes, J. M., Pincus, R., and John, V. O.: COSP: satellite simulation software for model assessment, B. Am. Meteorol. Soc., 92, 1023-1043, doi:10.1175/2011BAMS2856.1, 2011. 10552

Brogniez, $\mathrm{H}$. and Pierrehumbert, R. T.: Intercomparison of tropical tropospheric humidity in GCMs with AMSU-B water vapor data, Geophys. Res. Lett., 34, L17812, doi:10.1029/2006GL029118, 2007. 10552

Buehler, S. A. and John, V. O.: A simple method to relate microwave radiances to upper tropospheric humidity, J. Geophys. Res., 110, D02110, doi:10.1029/2004JD005111, 2005. 10551

Buehler, S. A., Kuvatov, M., Sreerekha, T. R., John, V. O., Rydberg, B., Eriksson, P., and Notholt, J.: A cloud filtering method for microwave upper tropospheric humidity measurements, Atmos. Chem. Phys., 7, 5531-5542, doi:10.5194/acp-7-5531-2007, 2007. 10551

Buehler, S. A., Kuvatov, M., John, V. O., Milz, M., Soden, B. J., Jackson, D. L., and Notholt, J.: An upper tropospheric humidity data set from operational satellite microwave data, J. Geophys. Res., 113, D14110, doi:10.1029/2007JD009314, 2008. 10551

Collins, W. J., Bellouin, N., Doutriaux-Boucher, M., Gedney, N., Hinton, T., Jones, C. D., Liddicoat, S., Martin, G., O'Connor, F., Rae, J., Senior, C., Totterdell, I., Woodward, S., Reichler, T., and Kim, J.: Evaluation of the HadGEM2 model, Met Office Hadley Centre, Tech. Rep. HTCN 74, Met Office, available at: http://library.metoffice.gov.uk/, 2008. 10552, 10553

Eliasson, S., Buehler, S. A., Milz, M., Eriksson, P., and John, V. O.: Assessing observed and modelled spatial distributions of ice water path using satellite data, Atmos. Chem. Phys., 11, 375-391, doi:10.5194/acp-11-375-2011, 2011. 10552

\section{ACPD}

13, 10547-10560, 2013

UTH in tropical

descent regions

V. O. John et al.

Title Page
Abstract

Conclusions

Tables

14

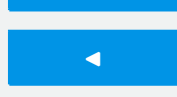

Back
Introduction

References

Figures

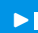

$>$

Close
Full Screen / Esc

Printer-friendly Version

Interactive Discussion 
Fasullo, J. T. and Trenberth, K. E.: A less cloudy future: the role of subtropical subsidence in climate sensitivity, Science, 338, 792-794, 2012. 10548

Hartmann, D. L. and Michelsen, M. L.: No evidence for IRIS, B. Am. Meteorol. Soc., 83, 249254, 2002. 10549

5 Held, I. M. and Soden, B. J.: Water vapor feedback and global warming, Annu. Rev. Energy Environ., 25, 441-475, 2000. 10549

Held, I. M. and Soden, B. J.: Robust responses of the hydrological cycle to global warming, J. Climate, 19, 5686-5699, doi:10.1175/JCLI3990.1, 2006. 10549

John, V. O. and Soden, B. J.: Temperature and humidity biases in global climate models and their impact on climate feedbacks, Geophys. Res. Lett., 34, L18704, doi:10.1029/2007GL030429, 2007. 10549

John, V. O., Buehler, S. A., and Courcoux, N.: A cautionary note on the use of Gaussian statistics in satellite based UTH climatologies, IEEE Geosci. Remote S., 3, 130-134, doi:10.1109/LGRS.2005.859350, 2006. 10551, 10553

John, V. O., Allan, R. P., and Soden, B. J.: How robust are observed and simulated precipitation responses to tropical ocean warming?, Geophys. Res. Lett., 36, L14702, doi:10.1029/2009GL038276, 2009. 10552

John, V. O., Holl, G., Allan, R. P., Buehler, S. A., Parker, D. E., and Soden, B. J.: Clear-sky biases in satellite infra-red estimates of upper tropospheric humidity and its trends, J. Geophys.

20 Res., 116, D14108, doi:10.1029/2010JD015355, 2011. 10551

John, V. O., Allan, R. P., Bell, B., Buehler, S. A., and Kottayil, A.: Assessment of inter-calibration methods for satellite microwave humidity sounders, J. Geophys. Res., in press, 2013a. 10550

John, V. O., Holl, G., Atkinson, N., and Buehler, S. A.: Monitoring scan asymmetry of microwave humidity sounding channels using simultaneous all angle collocations (SAACs), J. Geophys. Res., 118, 1536-1545, doi:10.1002/jgrd.50154, 2013b. 10550

Kottayil, A., Buehler, S. A., John, V. O., Miloshevich, L. M., Milz, M., and Holl, G.: On the importance of Vaisala RS92 radiosonde humidity corrections for a better agreement between measured and modeled satellite radiances, J. Atmos. Ocean. Tech., 29, 248-259, doi:10.1175/JTECH-D-11-00080.1, 2012. 10551

30 Lindzen, R. S., Chou, M.-D., and Hou, A. Y.: Does the earth have an adaptive infrared iris?, B. Am. Meteorol. Soc., 82, 417-432, 2001. 10549

UTH in tropical

descent regions

V. O. John et al.

Title Page 
McCarthy, M. P. and Toumi, R.: Observed interannual variability of tropical troposphere relative humidity, J. Climate, 17, 3181-3191, doi:10.1175/15200442(2004)017<3181:OIVOTT>2.0.CO;2, 2004. 10553

Milz, M., Buehler, S. A., and John, V. O.: Comparison of AIRS and AMSU-B monthly 5 mean estimates of upper tropopsheric humidity, Geophys. Res. Lett., 36, L10804, doi:10.1029/2008GL037068, 2009. 10551

Moradi, I., Buehler, S. A., John, V. O., and Eliasson, S.: Comparing upper tropospheric humidity data from microwave satellite instruments and tropical radiosondes, J. Geophys. Res., 115, D24310, doi:10.1029/2010JD013962, 2010. 10551

10 Pierce, D. W., Barnett, T. P., Fetzer, E. J., and Gleckler, P. J.: Three-dimensional tropospheric water vapor in coupled climate models compared with observations from the AIRS satellite system, Geophys. Res. Lett., 33, L21701, doi:10.1029/2006GL027060, 2006. 10549

Pierrehumbert, R. T.: Lateral mixing as a source of subtropical water vapor, Geophys. Res. Lett., 25, 151-154, 1998. 10548

15 Rayner, N. A., Parker, D. E., Horton, E. B., Folland, C. K., Alexander, L. V., Rowell, D. P., Kent, E. C., and Kaplan, A.: Global analyses of sea surface temperature, sea ice, and night marine air temperature since the late nineteenth century, J. Geophys. Res., 108, 4407, doi:10.1029/2002JD002670, 2003. 10552

Roca, R., Guzman, R., Lemond, J., Meijer, J., Picon, L., and Brogniez, H.: Tropical and extratropical influence on the distribution of free tropospheric humidity over the intertropical belt, Surv. Geophys., 33, 565-583, doi:10.1007/s10712-011-9169-4, 2012. 10548, 10553

Sherwood, S. C., Roca, R., Weckwerth, T. M., and Andronova, N. G.: Tropospheric water vapor, convection, and climate, Rev. Geophys., 48, RG2001, doi:10.1029/2009RG000301, 2010. 10548, 10549, 10553

Shi, L. and Bates, J. J.: Three decades of intersatellite-calibrated High-Resolution Infrared Radiation Sounder upper tropospheric water vapor, J. Geophys. Res., 116, D04108, doi:10.1029/2010JD014847, 2011. 10549, 10550

Soden, B. J. and Bretherton, F. P.: Interpretation of TOVS water vapor radiances in terms of layer-average relative humidities: method and climatology for the upper, middle, and lower so troposphere, J. Geophys. Res., 101, 9333-9343, doi:10.1029/96JD00280, 1996. 10551

Sohn, B. J. and Park, S. C.: Strengthened tropical circulations in past three decades inferred from water vapor transport, J. Geophys. Res., 115, D15112, doi:10.1029/2009JD013713, 2010. $10550,10552,10553$

\section{ACPD}

13, 10547-10560, 2013

UTH in tropical

descent regions

V. O. John et al.

Title Page

Abstract

Introduction

Conclusions

References

Tables

Figures

14

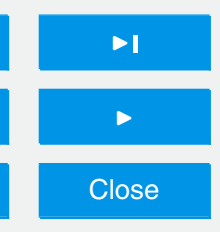

Back

Close

Full Screen / Esc

Printer-friendly Version

Interactive Discussion 


\section{ACPD}

13, 10547-10560, 2013

\section{UTH in tropical descent regions}
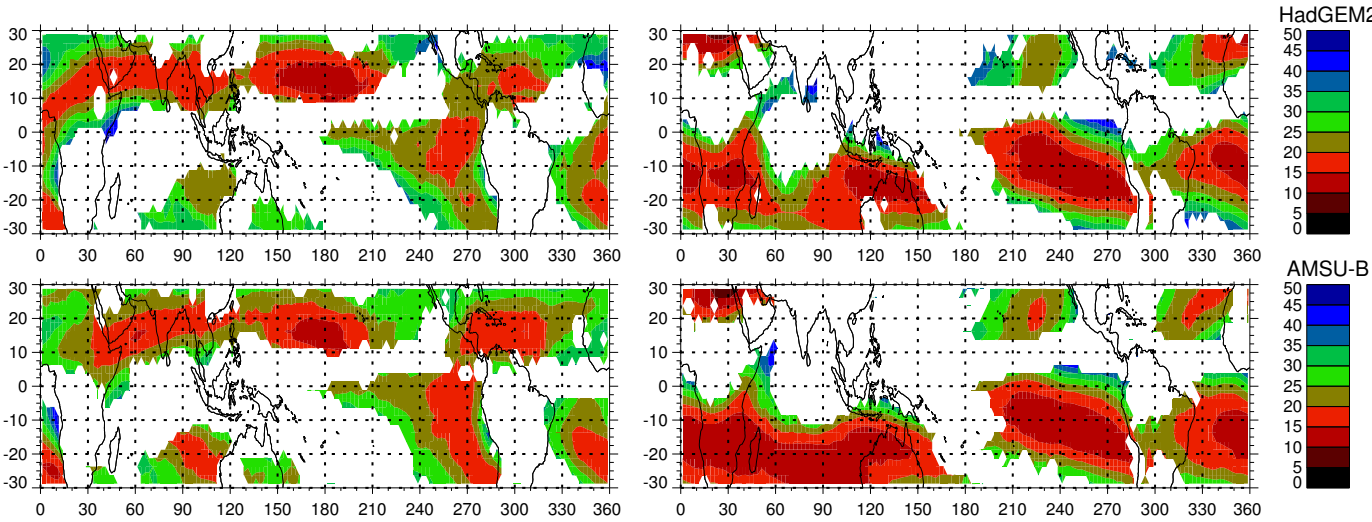

AMSU-B

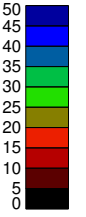

Fig. 1. UTH (expressed as \% RH) climatology for 1999-2008 of tropical descent regions for January (left panels) and July (right panels). Top panels show HadGEM2 UTH and bottom panels show observed (AMSU) UTH.
V. O. John et al.

Title Page

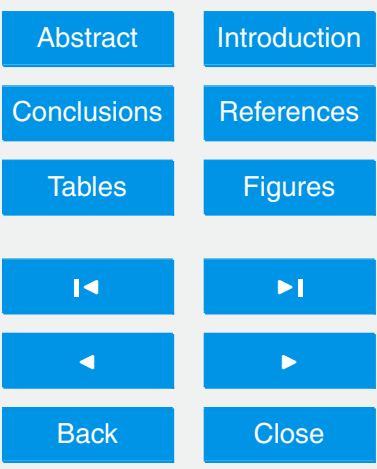

Full Screen / Esc

Printer-friendly Version

Interactive Discussion 


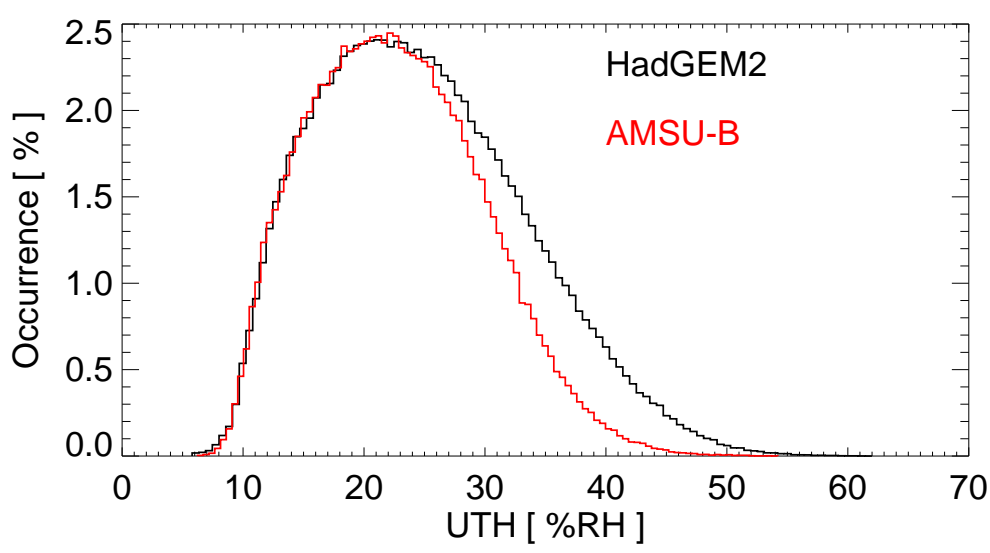

Fig. 2. Frequency distributions of UTH for 1999-2008 in tropical descent regions for HadGEM2 (black curve) and AMSU-B (red curve).

\section{ACPD}

13, 10547-10560, 2013

UTH in tropical descent regions

V. O. John et al.

Title Page

\section{Abstract}

Introduction

Conclusions

References

Tables

Figures

14

$>1$

4

Back

Close

Full Screen / Esc

Printer-friendly Version

Interactive Discussion 


\section{ACPD}

13, 10547-10560, 2013

\section{UTH in tropical descent regions}

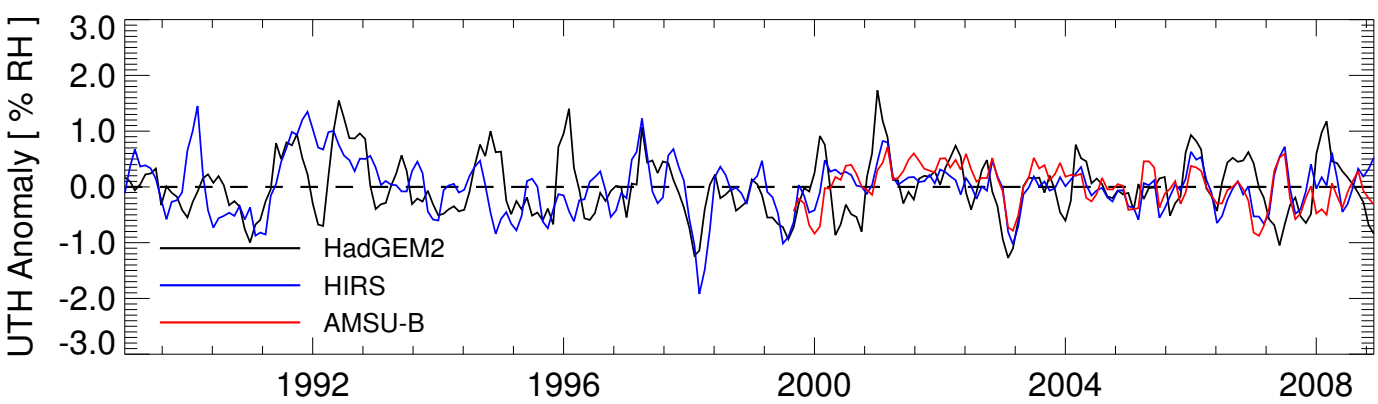

V. O. John et al.

Title Page

Fig. 3. Deseasonalised anomaly time series of tropical $\left(30^{\circ} \mathrm{S}-30^{\circ} \mathrm{N}\right)$ descent region UTH observed by HIRS and AMSU-B, and modelled by HadGEM2. Base time period used for calculating anomalies is 1999-2008. For clarity, each time series has been smoothed using a 3 month running mean. Tick-marks on the $x$-axis denote January of the indicated years.

14

$>1$

4

Back

Close

Full Screen / Esc

Printer-friendly Version

Interactive Discussion 